\title{
Training to Overcome Electronic-Information Poverty: An Australian Experience
}

\author{
Nicole Fahey \\ Deakin University, Australia
}

nicole a fahey@nag.national.com.au

\begin{abstract}
The rise of the information revolution has led to information becoming a major producer of wealth. This revolution has increased the importance of being able to access and utilise information from a variety of sources, including information published electronically. The Skills.net program was designed to increase electronic- information literacy skills by providing "free or low cost access to training in on-line services and the Internet for those in the community who are least likely to have access." (Cavill and Miller, 1998) This study found that the Skills.net program did increase electronic- information literacy. However the program was not as successful as it could have been, as it did not adequately address the accepted training needs of its participants.
\end{abstract}

Keywords: Information Poverty, Electronic-Information Poverty, Information Literacy, Electronic-Information-Literacy, Training, User-focussed evaluation, Information Revolution.

\section{Introduction}

The global economy is currently being transformed from an industrial economy into an information driven economy where information is a major producer of wealth. The utilisation and transformation of information is now a desirable way to produce wealth, and there is a growing importance for individuals to be able to access and interpret information from a variety of sources. (Kling 1996)

As the shift towards an information society progresses, information impoverished individuals will be unable to compete in the information economy, and as a consequence the gap between information 'haves' and 'have nots' will widen. (d'Orville 1998) These have nots will be faced with information poverty.

Information poverty is a relative form of poverty that leads to people being disadvantaged due to their lack of access to all types of information. There are many factors that

Material published as part of this proceedings, either on-line or in print, is copyrighted by the author with permission granted to the publisher of Informing Science for this printing. Permission to make digital or paper copy of part or all of these works for personal or classroom use is granted without fee provided that the copies are not made or distributed for profit or commercial advantage AND that copies 1) bear this notice in full and 2) give the full citation on the first page. It is permissible to abstract these works so long as credit is given. To copy in all other cases or to republish or to post on a server or to redistribute to lists requires specific permission from the author. contribute to information poverty including language, culture, poor English literacy skills, lack of access to telecommunications, the inability to use software and the lack of a recognised need to access electronic information.

As the information economy grows there will be an increased importance to access to electronic information. Those who cannot access electronic information will experience electronic-information poverty. (Fahey 2000)

In an attempt to reduce electronic-information poverty many nations have pledged to develop a Global Information Infrastructure, which if achieved will enable universal access to telecommunications. Many programs around the world have also implemented programs to improve general literacy skills in their communities such as reading, writing and mathematical skills.

Some Governments and Government agencies, such as the Victorian Government, the Canadian National Literacy Secretariat, the UK established National Council for Educational Technology and the Singapore Ministry for Education have implemented electronic-information literacy programs. (Miller 1997) These electronic-information literacy programs aim to increase a person's ability to use electronic means to extract and apply information.

The Victorian Government and Multimedia Victoria (MMV) designed the Community Skills and Networking 


\section{Training to Overcome Electronic-Information Poverty}

Program (Skills.net) to address the first objective of the Victoria 21: Into the Information Age policy to develop a multimedia skilled community.

Skills.net's purpose was "to provide free of charge or at a low cost access to training in on-line services and the Internet for those in the community who would otherwise not have access." (Cavill and Miller, 1998)

The Skills.net program attempts to reduce the widening gap between information rich and poor individuals by providing participants with training and access to computing facilities, thus allowing them to develop some degree of electronic-information literacy.

Information literacy is described by Charles McClure as "the ability to locate, process, and use information effectively regardless of delivery mechanisms and the type of format in which the information appears; that is, to be literate, one must be literate with both print and electronic formats." (McClure 1994) The term electronic-information literacy used throughout this study relates closely to McClure's definition. However electronic-information literacy only requires literacy in information presented in electronic formats.

This study discusses whether Skills.net training empowers participants by enabling them to develop a degree of electronic-information literacy.

\section{Research on Electronic-Information Literacy Training}

Although information literacy is extensively discussed in information systems, education and librarianship literature there has been no specific definition of the exact skills required to achieve electronic-information literacy.

In their report titled, 'Essential Skills for Information Literacy' (WLMA 1996), the Washington Library Media Association (WLMA) outlined what they identified as essential skills for information literacy.

The WLMA guidelines on skills for information literacy were used to assess whether Skills.net addressed accepted training needs and provided participants with the skills required to become literate in electronic information.

The three WLMA information skills used in this assessment were chosen because they could be directly related to the Web searching and email skills taught by Skills.net. These skill areas are discussed below.

1. Construct strategies for locating information.

Skills.net attempted to enhance participants' strategies for locating information by providing them with knowledge of additional information resources including the Web and email.

2. Locate and access information.

Skills.net training aimed to enable the location and accession of information via Internet searching and email.

3. Evaluate and extract information.

This skill relates to the participants' ability to identify whether information obtained is suitable to their need. Extraction of the information may simply be the ability to read and assimilate the information. However in this study extraction of information will relate to the participants ability to access information via electronic sources and locate it again for future use. Some of the methods which may be used to extract information are downloading, bookmarking and printing.

Three of Kirk and Todd's (in Booker 1993) guidelines for underpinning information literacy programs, were used to evaluate the ability of Skills.net to meet user needs throughout the design, development and delivery stages of training.

1. Information literacy is relative to the individual, a particular need and the situation of the individual. Therefore Skills.net training should be sensitive to participants needs.

2. Planning and development of the information literacy programs will be based on needs as determined by the users, not defined by the organisation.

3. Program evaluation needs to be evaluated in terms of users' needs, and the benefit and satisfaction derived.

\section{Research Objectives}

The main objective of this research was to investigate the ability of Skills.net to increase the electronic-information literacy of program participants while decreasing their relative electronic-information poverty. 
In order to determine the success of the Skills.net project and identify some underlying issues affecting its success it was necessary to develop a major research question as well as a set of sub questions to answer specific sub-issues. The formal research question is as follows:

\section{Does Skills.net training empower users?}

This question identifies whether Skills.net training meets participants electronic-information literacy training needs by addressing a set of sub-questions.

The sub questions address specific issues that have arisen out of a literature examination of the Skills.net program, including:

- Does Skills.net address accepted needs for training?

- Do Skills.net trainers believe they are achieving their goals of training?

- Do Skills.net participants think they are achieving their goals through Skills.net training? Are they satisfied with the skills they are taught?

This research attempts to contribute to the understanding of the effects of electronic-information literacy and electronic-information poverty. Also explored is the ability of access and training programs to overcome the effects of these phenomena.

\section{Skills.net Overview}

Skills.net was provided with five million dollars by MMV to be spent over three years in order to create a network of more than one hundred self-sustainable projects across Victoria. These projects originally aimed to provide forty thousand people with the skills and resources they need to understand and use the Internet. (Cavill and Miller 1998) The Skills.net network currently consists of three hundred and three projects across Victoria, which have provided training to over fifty-five thousand participants. (Skills.net 2001)

The Skills.net participants receive training from Leader Projects, which are provided with one hundred thousand dollars to train one thousand participants, or General Projects, which receive ten thousand dollars to train one hundred participants. Both types of projects are meant to provide five hours of training in the use of on-line technology, as well as, ten hours of access to the Internet for each participant. Original Skills.net projects known as pilot projects were only required to provide two hours of on-line training and ten hours of Internet access.

All applicants for Skills.net training must complete a survey, which asks the following.

- Do you have access to Internet services?

- Did you have access to Internet for 5 hours or more over the last six months?

- Do you have a multimedia computer at home, which has at any stage been connected to the Internet?

If the applicant answers yes to any of the above questions they may not eligible for Skills.net training.

\section{Skills.net Training Goals}

The training goals developed by MMV and VICNET suggest that all projects should provide training in Web browsing, email, downloading files and creating Web pages.

However there is general agreement amongst the projects that they can not cover this amount of training in the time allowed. (CIRCIT 1998) Therefore some projects have altered the training time and / or the type of training delivered.

According to a prior evaluation of Skills.net the most common format for the five-hour training is an introduction to the Internet, surfing and browsing the Web, an introduction to email and sending and receiving email (CIRCIT 1998).

MMV has previously evaluated a number of Leader and General Projects in terms of their ability to meet membership targets, training contact hours and access hours. This study differs from the MMV evaluation because it focuses on the quality of the training delivered and not the quantity.

\section{Research Methods Used}

Robson states, "The research strategy or strategies, and the methods or techniques employed, must be appropriate for the question that you want to answer." (Robson 1993)

In order to appropriately answer the main thesis question and its sub-questions, it was necessary to implement the 


\section{Training to Overcome Electronic-Information Poverty}

multiple case study research method and two separate data collection techniques. The primary data collection technique used was the survey. The survey was used to collect necessary quantitative data about Skills.net participants in order to answer the thesis sub-questions relating to participants perceived goals and satisfaction with training. The survey also asked participants to rate their pre-training and post-training skill levels. These skills level ratings were then used to allow the researcher to determine if the training empowered them by improving their skill level. This evaluation of empowerment contributed to the findings of the main thesis question, "Does Skills.net training empower participants?"

The survey also asked participants to rate their perceived importance of and satisfaction with various areas of the training. The results obtained from these questions combined with the reasons participants gave for undertaking the training, answered the third thesis sub-question, "Do participants think they are achieving their goals through Skills.net training?" From the 412 surveys successfully mailed to respondents 140 useable surveys were returned. This gave the survey a total response rate of $33.98 \%$.

The second data collection method used was a semistructured interview. The interview technique was used to assess the perceived needs and goals of the Skills.net trainers. This method enabled the collection of qualitative data relating to the trainer-related sub-question, the main thesis question and whether Skills.net addresses accepted needs for information literacy training. This research method also allowed the researcher to gain insight into the background and culture of the organisation.

\section{Results by Cases}

\section{Case One}

\subsection{Background of organisation}

Situated in a large rural community within the Central Victorian Skills.net region Case One was a well equipped and resourced learning centre largely focused on training teachers in IT skills before it received Skills.net funding. The Skills.net funding enabled them to bring forward by three years their long-term plan to extend training to the broader community. (CIRCIT 1998)

Case One was one of the pilot Leader Projects and as such was given funding to provide training for 1000 participants. The Skills.net training provided by this organisation consisted of an initial three-hour training session and nine hours of self guided access to Web and email technologies. The training session was an hour longer than Skills.net requirements to allow adequate coverage of the course requirements.

\subsection{Background of trainer}

The primary trainer at this case had been a trainer for five years and had experience in teaching computer applications such as MS Word, MS Office and Internet applications. They did not undertake any teacher training provided by VICNET because it was not available at the time, however they had received some in-house training some time before Skills.net training began.

\subsection{Demographics and sample size}

Of the groups studied this Case had trained the largest number of participants and therefore was sent the largest amount of surveys. Of the 216 surveys successfully sent 79 useable responses were returned, with the response rate being $36.57 \%$. This section explains the demographic composition of the people from this location that returned the survey.

\subsection{Age}

Table 1: Age of participants at Case One.

\begin{tabular}{|l|l|l|l|l|l|l|l|l|}
\hline & $19-25 y \mathrm{rs}$ & $26-35 y \mathrm{rs}$ & $36-45 y \mathrm{rs}$ & $46-55 y \mathrm{ys}$ & $56-65 y \mathrm{rs}$ & $66-75 y \mathrm{rs}$ & $76 \mathrm{ys}+$ & Total \\
\hline Case 1 & $5.19 \%$ & $11.69 \%$ & $25.97 \%$ & $29.87 \%$ & $1299 \%$ & $11.69 \%$ & $260 \%$ & $100.00 \%$ \\
\hline
\end{tabular}

Over fifty-five percent of the trainees surveyed at Case One were aged between 36-55 years. According to the Australian Bureau of Statistics (ABS) 29\% of people aged between 40-54 years are likely to have had access to the Internet. (ABS 1998) Therefore it is probable that the participants trained at this location only had moderate access to the Internet in the past. Also because this training centre was located in a rural region it is likely that respondents have had less access to the Internet than people from a metropolitan area. (ABS 1998)

\subsection{Gender}

Over seventy percent of those surveyed at this location were women. As this location had a large proportion of 
female trainees their Internet accession rate and skill level may be lower than expected. This is due to women being less likely to access the Internet than men. In 1997/98 34\% of men accessed the Internet access compared with $28 \%$ of women. (ABS 1998)

Table 2: Gender at Case One.

\begin{tabular}{|l|l|l|l|}
\hline & Male & Female & Total \\
\hline Case 1 & $29.49 \%$ & $70.51 \%$ & $100.00 \%$ \\
\hline
\end{tabular}

\subsection{Satisfaction with training}

Table 3: Overall Satisfaction Case One.

\begin{tabular}{|l|l|l|l|l|l|l|}
\hline & V. Sat. & Sat. & Indiff. & Dis. & V.Dis. & Total \\
\hline Case 1 & $19.23 \%$ & $53.85 \%$ & $15.38 \%$ & $10.26 \%$ & $1.28 \%$ & $100.00 \%$ \\
\hline
\end{tabular}

Case One was less satisfied with the training they received with few participants claiming to be very satisfied with the course. They were significantly less satisfied than other groups with teaching support, reliability of equipment and course content, although they were more satisfied with the ten hours of Internet access provided.

\subsection{Summary}

Overall Case One was less satisfied with Skills.net training than other cases. This lack of satisfaction may have been a result of the short (three hour) duration of this training course. To rectify this problem Skills.net now provide at least five hours of training to all participants.

This case felt that the Skills.net designed training areas were slightly less important than the other groups studied. Although they were more satisfied with the with the Internet access provided than the other groups.

\section{Case Two}

\subsection{Background of organisation}

Like Case One, Case Two was a pilot Leader Project required to provide training to 1000 participants. However Case Two differed from the other cases studied because it was not established before Skills.net funding was granted. This case was funded as a 'start up project' to service a small rural community in the South Western Victorian re- gion and was the result of a joint partnership between local Government and the local University.

Case Two's vision was "to facilitate the uptake and use of multimedia technology and the development of multimedia skills in the region by all sectors of the community and develop opportunities for establishing a multimedia industry through providing hands on experience, training and use of multimedia technology in a non-threatening, flexible and professional environment." (Case Two Interviewee 1999)

This case provided ten hours of training to its participants in the form of five two-hour sessions, which allowed them to provide more training than other organisations adhering to Skills.net guidelines.

\subsection{Background of trainer}

The primary trainer at this organisation had worked as a teacher for 13-14 years and had several formal qualifications in this area. Due to their knowledge of curriculum development and design they were employed as the Project Facilitator and as such played a large role in developing the curriculum taught at this venue.

Although this trainer had no previous specific information technology teaching experience they had experience at teaching music-related technology.

\subsection{Demographics and sample size}

Case Two was sent 132 surveys and returned 44 useable responses, giving a response rate of $33.33 \%$. This section describes the demographic features of those from Case Two who returned the survey.

\subsection{Age}

Table 4: Age of participants at Case Two.

\begin{tabular}{|l|l|l|l|l|l|l|l|l|}
\hline & $19-25 y r s$ & $26-35 y r s$ & $36-45 y r s$ & $46-55 y r s$ & $56-65 y r s$ & $66-75 y r s$ & $76 y r s+$ & Total \\
\hline Case22 & $233 \%$ & $4.65 \%$ & $233 \%$ & $11.63 \%$ & $23.26 \%$ & $46.50 \%$ & $9.30 \%$ & $100.00 \%$ \\
\hline
\end{tabular}

Almost seventy percent of those surveyed at Case Two were between the ages of 56-75 years at the time they were surveyed. According to an ABS survey only $7 \%$ of people aged over 55 years accessed the Internet in the 12 month period ending in November 1998. (ABS 1998) As this training was located in a rural region their respondents 


\section{Training to Overcome Electronic-Information Poverty}

were less likely to have had access to the Internet. (ABS 1998) Due to the age, gender and location of Case Two participants they were likely to be the least skilled before undertaking training.

\subsection{Gender}

Table 5: Gender at Case Two.

\begin{tabular}{|l|l|l|l|}
\hline & Male & Female & Total \\
\hline Case 2 & $37.21 \%$ & $62.79 \%$ & $100.00 \%$ \\
\hline
\end{tabular}

Like Case One, the majority of survey respondents were women. However there was a slightly more even distribution with only $62.79 \%$ of respondents being female.

Women in general were $4 \%$ less likely to have access to the Internet than men. (ABS 1998) This again may reduce the skill level found at this location.

\subsection{Satisfaction with training}

Overall Case Two respondents were moderately satisfied with the training they received. In general the satisfaction levels reported by this group fell between those of Case One and Case Three.

Table 6: Overall Satisfaction Case Two.

\begin{tabular}{|l|l|l|l|l|l|l|}
\hline & V. Sat. & Sat. & Indiff. & Dis. & V.Dis. & Total \\
\hline Case 2 & $25.58 \%$ & $58.14 \%$ & $11.63 \%$ & $4.65 \%$ & $0.00 \%$ & $100.00 \%$ \\
\hline
\end{tabular}

\subsection{Summary}

As expected Case Two respondents consistently reported lower skill levels than the other groups before and after training. The only exceptions were in the areas of Internet searching, email, and Internet history, where the groups reported skill levels very similar to those of Case One. Apart from feeling less skilled than the other groups. This case viewed the majority of training areas as moderately important. Although they perceived Internet searching, Internet history and downloading as less important than other groups.

\section{Case Three}

\subsection{Background of organisation}

Case Three was a General Project, which conducted training from a community centre in the Melbourne metropolitan Skills.net region. This Case began conducting Skills.net training in early March 1998. However since the community centre's inception in 1973 they have aimed to provide programs to enhance social justice, access and equity to its community. Case Three also attempt to provide lifelong learning opportunities to all individuals regardless of age, gender, race or disability. (Anonymous 1999)

Case Three provided five hours of online training and ten hours of access to it's participants as outlined in the Skills.net guidelines. However they were flexible and would alter the course content to suit participant needs.

\subsection{Background of trainer}

The Skills.net trainer at this location was employed on a sessional basis to deliver Skills.net and Adult Literacy training. Like Case Two the trainer at this location had significant teaching experience in areas other than information technology. Although the trainer had no formal information technology training experience or qualifications they had been incorporating the use of information technology into their literacy teaching for some time.

\subsection{Demographics and sample size}

Case Three had the smallest number of trained participants to survey, as it was a General Project and was only required to train 100 Skills.net participants. Therefore only 64 surveys were sent to this location and only 17 useable responses were returned. The response rate from this case was lower than the other cases at $26.56 \%$, and the trainer of this case suggested that this might be a result of the high Non-English Speaking Background (NESB) population at this venue. The section below explains the demographic features of the survey respondents from this case.

\subsection{Age}


Table 7: Age of participants at Case Three.

\begin{tabular}{|l|l|l|l|l|l|l|l|l|}
\hline & $19-25 y r s$ & $26-35 y r s$ & $36-45 y r s$ & $46-55 y r s$ & $56-65 y r s$ & $66-75 y r s$ & $76 y r s+$ & Total \\
\hline Case3 & $0.00 \%$ & $23.53 \%$ & $23.53 \%$ & $17.65 \%$ & $5.88 \%$ & $11.76 \%$ & $17.65 \%$ & $100.00 \%$ \\
\hline
\end{tabular}

Case Three had the youngest population of all the cases surveyed, with over forty percent of respondents aged between 26-45 years. As 40\% of Australian's aged between 25-39 years were likely to have had access to the Internet this group was the most likely to have access of the groups studied. The respondents at this case were also more likely to have access to the Internet as the course was located in a metropolitan area. (ABS 1998) This increased likelihood of access may result in the skill level of this group being higher than the other cases.

\subsection{Gender}

Table 8: Gender at Case Three.

\begin{tabular}{|l|l|l|l|}
\hline & Male & Female & Total \\
\hline Case 3 & $58.82 \%$ & $41.18 \%$ & $100.00 \%$ \\
\hline
\end{tabular}

This case differed from the other two studied because the majority of survey respondents were male. As men are more likely to have access to the Internet this case may have been the most electronic-information literate group before the training.

\subsection{Satisfaction with training}

Case Three was the most satisfied case studied. This high satisfaction was demonstrated with significantly higher perceived satisfaction with their teacher and the course content.

Table 9: Overall Satisfaction Case Three.

\begin{tabular}{|l|l|l|l|l|l|l|}
\hline & V. Sat. & Sat. & Indiff. & Dis. & V.Dis. & Total \\
\hline Case 3 & $60.00 \%$ & $26.66 \%$ & $6.67 \%$ & $6.67 \%$ & $0.00 \%$ & $100.00 \%$ \\
\hline
\end{tabular}

\subsection{Summary}

In pre-training and post-training categories Case Three respondents considered themselves slightly more skilled in most areas than the other locations. These results were consistent with the ABS findings that this group should have had more access to Internet and information technology and therefore should be more skilled.

Case Three participants also placed higher importance on most of the training areas than the other groups, which may have been because they had more of an idea of what to expect from training as they were more experienced at using computers.

\section{Summary of Findings}

\section{Does Skills.net Address Accepted Needs for Training?}

To determine if Skills.net training addressed accepted training needs, information about the programs design, development and delivery was analysed and compared to the guidelines for successful information literacy training by WLMA and Kirk and Todd. To address the WLMA guidelines the training had to enable students to construct strategies for locating, accessing, evaluating and extracting information.

\section{Constructing strategies for locating information}

Skills.net addressed this guideline by providing participants with knowledge of information resources including the Web and email. Once participants had knowledge about how these information resources could help them locate information, they could include the use of these resources into their information gathering strategies.

\section{Locate and access information}

The program addressed this area by providing training in skills, which enabled access to information by using the Web and email. The training also provided students with the ability to refine and narrow Web searches to allow them to locate the most relevant information for their needs.

\section{Evaluate and extract information}

The training enabled participants to evaluate and extract information. The ability to evaluate information was beyond the scope of this course, however Skills.net teaches participants how to extract suitable information for future use. Although the amount of training given on information extraction differed between Skills.net groups some meth- 


\section{Training to Overcome Electronic-Information Poverty}

ods taught included bookmarking, downloading / saving and printing.

\section{Information literacy is relative to the individual, a particular need and the situation of the individual.}

In order to meet the guidelines established by Kirk and Todd Skills.net training had to demonstrate a user orientation to the design, development and delivery of their training.

Therefore Skills.net training needed to be sensitive to participants needs. Skills.net training was designed to teach a standard set of skills to training participants and therefore did not allow a great deal of flexibility to enable trainers to meet individuals needs. Skills.net trainers often altered the content of Skills.net training to be more suitable to the skill level and needs of the group being instructed. For example Case One would provide extra training exercises for those who were unfamiliar with using a mouse, to provide them with the mouse skills necessary to navigate the Web.

\section{Planning and development of information literacy programs will be based on needs as determined by the users, not defined by the organisation.}

Skills.net was not successful in this area because the training program was designed on the basis of user needs determined by MMV and VICNET. There did not appear to be any prior studies by these organisations that identified a set of user needs to be addressed. Therefore it is likely that these organisations based the training, on needs of participants from other training courses or their own perceived needs.

As a result of the training needs being defined by MMV and VICNET several proposed training areas such as creating Web pages were far too advanced for participants.

Also, participants did not view some areas such as the history of the Internet as relevant. Therefore trainers were forced to redesign the training to suit participants requirements, creating inconsistency in training between the projects.

Program evaluation needs to be evaluated in terms of users' needs, and the benefit and satisfaction derived.

Although a prior evaluation of Skills.net recommended investigation into the satisfaction of participants (CIRCIT
1998) until this study, no such evaluation of user needs, benefit or satisfaction has been undertaken. Therefore Skills.net training was unsuccessful in this area. Skills.net appears to be achieving mixed success in its ability to meet accepted needs of training. While the program is fairly successful in achieving relevant WLMA guidelines for teaching information literacy, the training did not meet user needs adequately enough to be successful in terms of the Kirk and Todd guidelines.

\section{Do Skills.net Trainers believe they are achiev- ing Their Goals of Training?}

The cases studied had different mission statements and slightly different training goals, however all trainers believed that their organisation was successful at achieving its goals through the provision of Skills.net training. It must be noted that this section measures the perceptions of the trainers in this regard, and these perceptions may differ from reality.

Case One believed they were successful because they seemed to meet most of VICNET and MMV's training targets while providing training to the broader community. Case Two met their goals by providing training to those in the broader community who were potentially disenfranchised by not having access to the Web and email. Case Three provided training to individuals regardless of age, gender, race or disability. This organisation exceeded its aims of Skills.net training and was successful at achieving most of VICNET and MMV's training goals.

\section{Do participants think they are achieving their goals through Skills.net training? Are they satisfied with the skills they are taught?}

The most frequently chosen reasons for undertaking Skills.net training were to develop computer skills or explore a new area of interest. Again it is important to note that the findings in this area were based on the perceptions of users.

It appears that Skills.net training is successful at developing computer skills because most of the participants perceived themselves as more skilled after completing the training. Therefore it is inferred that participants met their goals in this area.

The ability of Skills.net to enable participants to explore a new area of interest is somewhat more difficult to deter- 
mine, due to a lack of specific questions relating to this area.

Overall, participants were satisfied with the skills they gained through Skills.net training, even when they did not view the training area as particularly relevant, as in the case of Internet history.

As the satisfaction findings were based on participants perceptions and not skill level testing, it cannot be adequately determined if the skill levels achieved were of a satisfactory standard.

\section{Does Skills.net training empower users?}

The trainer at Case One saw Skills.net training empower users by providing them with the basic skills necessary to explore their areas of interest. They also believe that Skills.net training empowered users by allowing them to "air their views publicly via the use of email".

Although feeling that empowerment is a difficult thing to quantify the primary trainer at Case Two believed that Skills.net training raised the awareness of participants which could be empowering. The trainer also felt that the degree of empowerment achieved by the training depended on "what people are expecting to get out of it".

The trainer at Case Three believed that Skills.net training empowered people by providing them "with a new set of information communication ... and information gathering possibilities."

The findings in relation to increases in skills and satisfaction with training suggest that Skills.net training did to some degree empower participants by providing them with skills to access a broader range of information resources.

However as the course did not focus closely enough on the needs of its participants it did not provide the degree of empowerment in participants that it could have.

\section{Conclusions}

The Skills.net program was a well-meaning initiative designed to increase the electronic-information literacy of information poor individuals. However the potential impact of the Skills.net program on increasing electronicinformation literacy was limited due to the failure of the program to adequately address accepted training guidelines.
Skills.net did appear to meet the WLMA guidelines for constructing strategies to locate, assess, evaluate and extract information. However the depth to which these areas were taught and the time spent teaching them varied greatly between the training venues. Therefore it may have not been Skills.net's original design that met user needs in this area, but instead the trainers' modifications to the course structure. These discrepancies made evaluation of the program difficult.

The major failing of Skills.net was that during its development there was no consultation with potential Skills.net participants to determine what their needs were from the training. This meant that the course was developed on what MMV and VICNET believed to be the needs of potential participants and not the actual needs of participants.

However this study appears to demonstrate the effectiveness and applicability of the WLMA and Kirk and Todd evaluation guidelines to aid in the development, implementation and evaluation of electronic-information literacy training programs. Results from the study appear to indicate that Skills.net participants want strategies for locating, extracting and evaluating information concurring with the WLMA guidelines.

The findings of the study also imply that Skills.net would have been more effective if it had taken into account the Kirk and Todd guidelines and focussed on user needs during its design, development, implementation and evaluation. Although developing an effective electronicinformation literac ycourse design was outside the scope of this evaluation it would be worthwhile for Skills.net (MMV and VICNET) to adhere to the accepted guidelines while developing future electronic-information literacy training courses. This would ensure that the course design is as effective as possible at meeting user needs while improving information literacy.

\section{Acknowledgments}

I would like to thank to the Skills.net coordinator, trainers and participants for their contributions to the research.

I would also like to thank John Lamp, my boyfriend, friends, family and workplace for providing me with continued support. 


\section{Training to Overcome Electronic-Information Poverty}

\section{References}

Anonymous. (1999) Motivating Philosophy. [online] Available at: http://home.vicnet.net.au/ dukest/aboutduk.htm\#motivating philosophy [17/6/99]

Australian Bureau of Statistics. (1998) Use of the Internet by Householders. Australian Bureau of Statistics. Canberra. AGPS.

Booker, D. ed. (1993) Information Literacy, the Australian Agenda: Proceedings of a Conference. University of South Australia Library. Adelaide.

Cavill, M. and Miller, S. (1998) Report to Multimedia Victoria. Evaluation of the Community Skills and Networking (Skills.net) Program. Melbourne. CIRCIT, Ltd.

CIRCIT. (1998). Report to Multimedia Victoria. Evaluation of the Community Skills and Networking (Skill.net) Program. Melbourne, CIRCIT, Ltd.

d'Orville, H. (1996) The Information and Knowledge Revolutions - The Advent and Impact Of Generic Technologies. [online] Available at: http://www.undp.org/comm/page1.htm. Accessed: [12/8/98].

Dillman, D.A. (1978) Mail and Telephone Questionnaires. The Total Design Method. USA. John Wiley and Sons, Inc.

Dwyer, J. (1993) The Business Communication Handbook. Third Edition. Prentice Hall.

Fahey, N. (1999) An Investigative Report into Client Empowerment and the Skills.net Project. Deakin University[online] Available at: http://www.skills.net.au/download/BCHthesis.pdf: [4/8/2000]

Kling, R. ed. (1996) Computerization and Controversy: Value Conflicts and Social Choices. 2nd Edition. Academic Press Inc. USA.
McClure, C. (1994) Network Literacy: A Role for Libraries. Information Technology and Libraries. 13(2). pp.115-125.

Miller, S. (1997) International Approaches to Skills Development in the Use of Information and Communication Services. Vol. 15. . CIRCIT, Ltd. Melbourne

Multimedia Victoria (1999) Multimedia Victoria Website. [online] Available at: http://www.mmv.vic.gov.au/. Accessed: [5/6/99].

Neuman, W. L. (1997) Social Research Methods: Qualitative and Quantitative Approaches. Third Edition. Allyn and Bacon.

Robson, C. (1993) Real World Research: A Resource for Social Scientists and Practitioner-Researchers. Blackwell Publishers Inc.

Skills.net (2000) Skills.net Website. [online] Available at: http://www.skills.net.au/. Accessed: [4/3/2001]

Washington Library Media Association Online (1996) Essential Skills for Information Literacy, Washington

Library Media Association Online. [online] Available at: http://wlma.org/literacy/eslintro.htm\#esbench Accessed:[13/11/98].

\section{Biography}

Nicole Fahey has had a consistent interest in issues surrounding information literacy, information poverty and the digital divide since undertaking research in this area in 1998, which lead to her BCom(Hons), at Deakin University, Australia. Nicole is keen to promote the importance of training communities to become information literate and speaks frequently on the need for information literacy training. 